Slavia Antiqua

LX (2019)

DOI: $10.14746 /$ sa.2019.60.19

MILENA TESKA*

\title{
OBCHODY 100-LECIA ISTNIENIA ARCHEOLOGII POZNAŃSKIEJ NA UNIWERSYTECIE IM. ADAMA MICKIEWICZA
}

Każdy jubileusz skłania do refleksji - można przeczytać na stronie poświęconej 100. rocznicy powołania do życia Uniwersytetu Poznańskiego, przez rok funkcjonującego pod nazwą Wszechnicy Piastowskiej. Rok 2019 bowiem to czas szczególny, to czas wielu jubileuszy. To czas, w którym cztery poznańskie uczelnie - Uniwersytet im. Adama Mickiewicza, Uniwersytet Medyczny im. Karola Marcinkowskiego, Uniwersytet Przyrodniczy, Akademia Wychowania Fizycznego im. Eugeniusza Piaseckiego - niegdyś integralne jednostki Uniwersytetu Poznańskiego, celebrowały swój Jubileusz Stulecia. Jest to także rocznica ustanowienia Seminarium Prehistorycznego, co zasadniczo miało miejsce 30 stycznia 1919 roku. Instytut Archeologii, kilkakrotnie zmieniający swą nazwę, jest zatem jedną z najstarszych komórek naukowych, a prehistoria - archeologia jednym z najstarszych kierunków, uruchomionych w ramach powołanej Alma Mater Posnaniensis. Jego pierwszym dyrektorem był Profesor Józef Kostrzewski - członek Komisji Organizacyjnej Uniwersytetu Polskiego w Poznaniu i inicjator wykładów otwartych, służących promowaniu uczelni i nauki.

Instytut Archeologii Uniwersytetu im. Adama Mickiewicza w Poznaniu w pełni zaangażował się w tegoroczne obchody, czując się spadkobiercą bogatej spuścizny Profesora Kostrzewskiego, a jednocześnie czyniąc refleksję nad upływającym czasem, czego widomym znakiem były między innymi trzy wydarzenia kulturalne zorganizowane $\mathrm{w}$ ramach tychże obchodów.

23 lutego bieżącego roku odbył się pierwszy w historii Instytutu Zjazd Absolwentów Archeologii Poznańskiej. W jego ramach przewidziano spacer po Poznaniu, śladem wszystkich siedzib Instytutu, tj. Collegium Juridicum, Collegium Novum, na starym gmachu Collegium Historicum kończąc. Oficjalne rozpoczęcie Zjazdu nastąpiło w nowej siedzibie Collegium Historicum przy obecnej ulicy Uniwersytetu Poznańskiego 7, w Auli im. Profesora Gerarda Labudy (fot. 1). W trakcie tego

* ORCID: 0000-0002-0685-5750; Wydział Archeologii UAM, ul. Uniwersytetu Poznańskiego 7, 61-614 Poznań, e-mail: m.teska@amu.edu.pl. 
spotkania powołano do życia Stowarzyszenie Absolwentów Instytutu Archeologii UAM. Zwieńczeniem Zjazdu był bankiet zorganizowany w siedzibie Wydziału Historycznego.

W dniu 8 maja z kolei, na Wydziale Historycznym UAM, miało miejsce sympozjum „100 lat poznańskiej archeologii uniwersyteckiej”, w którym jako prelegenci głos zabrali badacze $\mathrm{z}$ innych polskich instytucji akademickich i naukowych (fot.2). Konferencja została pomyślana w taki sposób, aby zaprezentować, jak archeologia poznańska postrzegana jest $\mathrm{w}$ środowisku naukowym. $\mathrm{Z}$ uwagi na powyższe, w trakcie obrad poruszono następujące tematy i zagadnienia:

Paleolit i mezolit $w$ Polsce $i$ na świecie $w$ badaniach archeologów ośrodka poznańskiego - Jan Burdukiewicz (Instytut Archeologii Uniwersytetu Wrocławskiego),

Kilka uwag o polskich badaniach nad neolitem i miejscu w nich dokonań poznańskich - Janusz Kruk (Instytut Archeologii i Etnologii PAN, Ośrodek Archeologii Gór i Wyżyn w Krakowie),

Poznańska archeologia wczesnej epoki brązu - Sławomir Kadrow (Instytut Archeologii Uniwersytetu Rzeszowskiego),

Wkład poznańskiego ośrodka uniwersyteckiego w badania nad młodsza epoka brazu i wczesna epoka żelaza - Sylwester Czopek (Instytut Archeologii Uniwersytetu Rzeszowskiego),

Dokonania poznańskiego ośrodka akademickiego w badaniach nad okresem lateńskim, rzymskim i wędrówek ludów - Artur Błażejewski (Instytut Archeologii Uniwersytetu Wrocławskiego),

Wczesne średniowiecze $w$ badaniach archeologów uniwersytetu poznańskiego. Tradycja i teraźniejszość - Wojciech Chudziak (Instytut Archeologii Uniwersytetu Mikołaja Kopernika w Toruniu),

Poznańska archeologia późnego średniowiecza i nowożytności - Jerzy Piekalski (Instytut Archeologii Uniwersytetu Wrocławskiego),

Archeolodzy z UAM i odkrywanie pótnocnej Mezopotamii - Piotr Bieliński (Centrum Archeologii Śródziemnomorskiej Uniwersytetu Warszawskiego),

Aktywność badawcza Instytutu Archeologii Uniwersytetu im. A. Mickiewicza w strefie egejskiej - Ewdoksia Papuci-Władyka (Instytut Archeologii Uniwersytetu Jagiellońskiego),

Pontyjskie dokonania archeologów z uniwersytetu poznańskiego - Jan Chochorowski (Instytut Archeologii Uniwersytetu Jagiellońskiego),

Rola poznańskiego środowiska archeologicznego w ochronie zabytków archeologicznych 1919-2019 - Zbigniew Kobyliński (Instytut Archeologii Uniwersytetu Kardynała Stefana Wyszyńskiego w Warszawie),

Metodologia archeologii na Uniwersytecie im. Adama Mickiewicza w Poznaniu - Henryk Mamzer (Instytut Archeologii i Etnologii PAN, Ośrodek Studiów Pradziejowych i Średniowiecznych w Poznaniu),

Podsumowanie - Andrzej Buko (Instytut Archeologii i Etnologii PAN, Ośrodek Interdyscyplinarnych Badań Archeologicznych w Warszawie). 


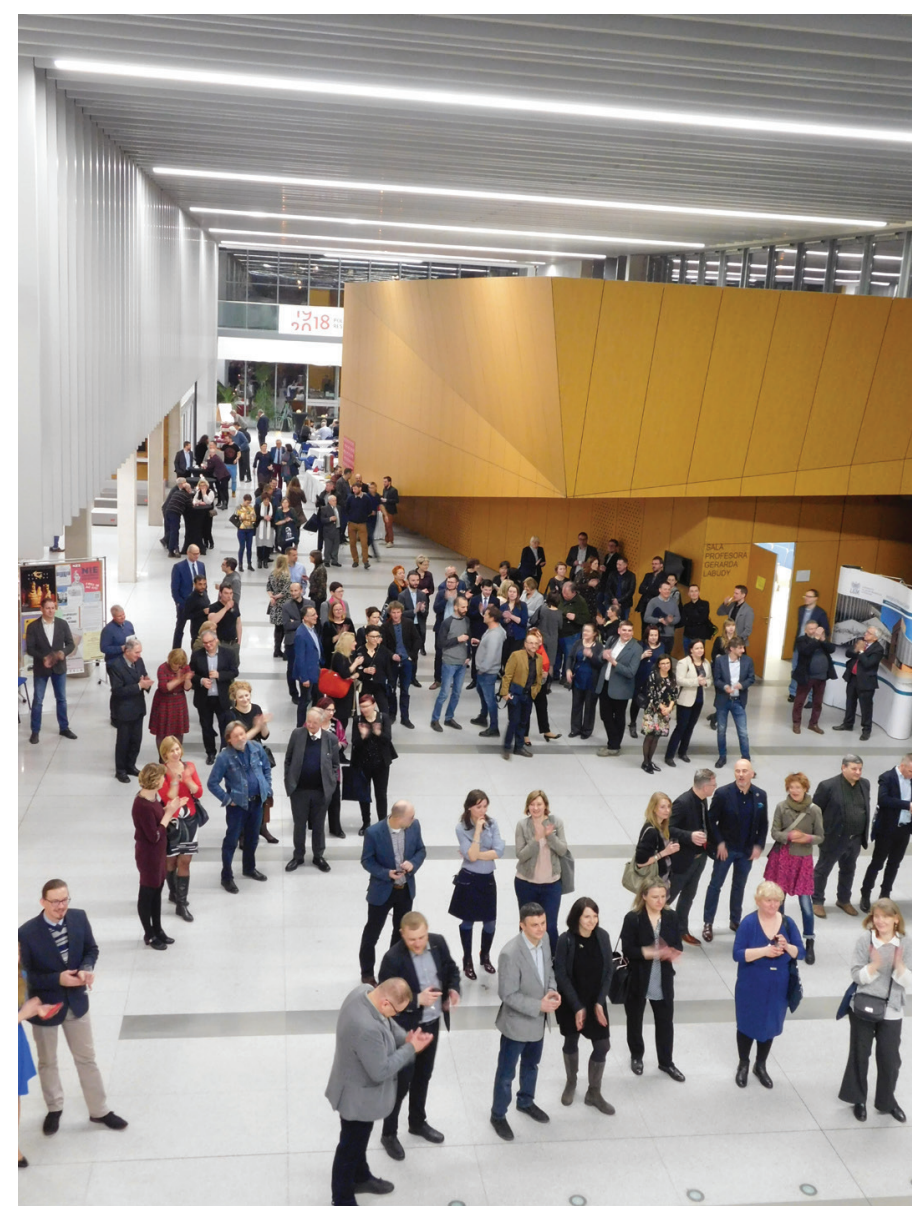

Fot. 1. Uczestnicy pierwszego w historii Instytutu Zjazdu Absolwentów Archeologii Poznańskiej przed Aulą im. Profesora Gerarda Labudy. Fot. P. Majorek

Sympozjum było doskonałą okolicznością do poczynienia wielu miłych wspomnień, do dyskusji na temat przeszłości, przyszłości oraz kondycji archeologii w ogóle, do wielu inspirujących rozmów, które toczyły się zarówno na sali obrad, jak i w kuluarach.

Jubileusz 100 lat archeologii akademickiej w Poznaniu, zgodnie z tym, co napisano powyżej, był zarówno okazją do spojrzenia w przeszłość, jak i najlepszym momentem do snucia planów na przyszłość, czego odzwierciedleniem była również wystawa pt. „Skarby czasu. Badania Instytutu Archeologii Uniwersytetu im Adama Mickiewicza w Poznaniu", zaaranżowana w poznańskim Muzeum Archeologicznym (fot. 3). Rzeczona ekspozycja, a także jej albumowe wydanie, mają i miały na celu zaprezentowanie różnorodności i bogactwa osiągnięć naukowych oraz dy- 


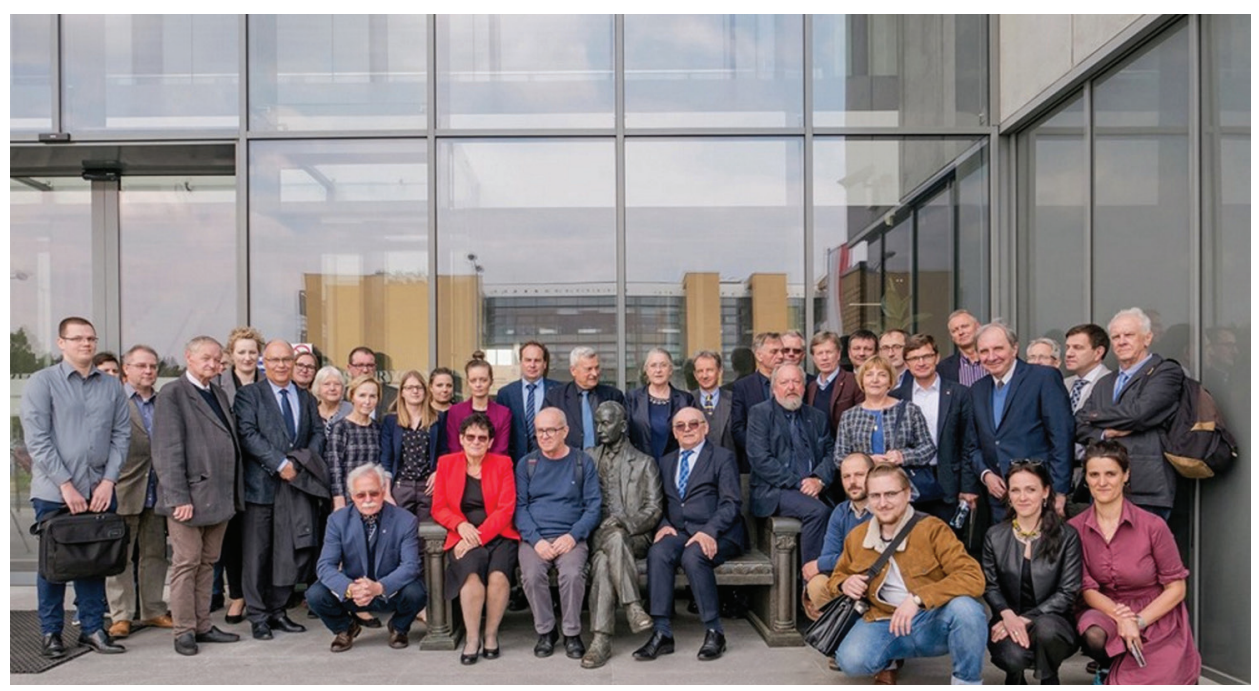

Fot. 2. Uczestnicy sympozjum „100 lat poznańskiej archeologii uniwersyteckiej” przy ławeczce Profesora Józefa Kostrzewskiego przed nowym gmachem Collegium Historicum. Fot. M. Kaczmarek

daktycznych archeologów z Uniwersytetu im. Adama Mickiewicza w Poznaniu w tym szczególnym momencie historii. Publikacja i towarzysząca jej wystawa tylko w pewnym stopniu przybliżyły zakres zainteresowań badawczych ośrodka poznańskiego. $\mathrm{W}$ ich bezpośrednim kręgu znajdują się bowiem znacznie szersze studia, między innymi w zakresie:

- środowiskowych uwarunkowań najstarszego osadnictwa Europy Środkowej,

- rozwoju kulturowego Niżu Europejskiego w epoce kamienia i wczesnej epoce metali,

- syntezy wczesnej epoki brązu,

- pogranicza biokulturowego Wschodu i Zachodu Europy w pradziejach i starożytności,

- powiązań kulturowych cywilizacji egejskiej z Europą Środkową,

- archeologii starożytnego Bliskiego Wschodu,

- powiązań kulturowych Wielkopolski z terenami ościennymi w późnym okresie brązu i we wczesnej epoce żelaza,

- sztuki społeczności Europy Środkowej w epoce żelaza,

- sztuki Grecji i Italii,

- problematyki europejskiego Barbaricum w młodszym okresie przedrzymskim, wpływów rzymskich i wędrówek ludów,

- obszarów prowincjonalnorzymskich w Europie

- kontynuacji między starożytnością a wczesnym średniowieczem w Polsce, 


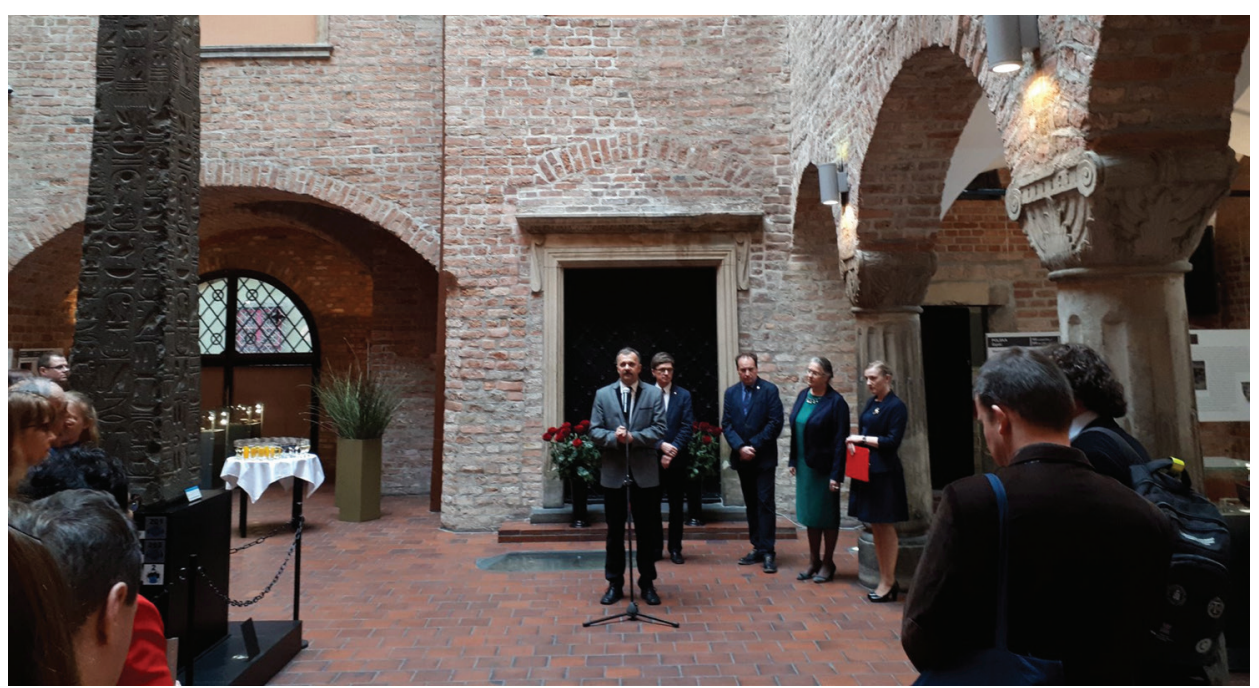

Fot. 3. Otwarcie wystawy „Skarby czasu. Badania Instytutu Archeologii Uniwersytetu im. Adama Mickiewicza w Poznaniu". Fot. Ł. Bartkowiak

- etnogenezy Słowian,

- początków władztwa Piastów,

- architektury i sztuki Polski średniowiecznej,

- teorii i metodologii archeologii.

W ośrodku poznańskim rozwijane są ponadto studia interdyscyplinarne, zorientowane na:

- prospekcję geofizyczną,

- prospekcję lotniczą,

- metody geoarcheologiczne,

- metody tafonomiczne,

- metody traseologiczne,

- analizy archeometryczne,

- analizy rentgenowskie.

Podczas majowych obchodów 100-lecia Uniwersytetu Poznańskiego przed Aulą UAM umieszczono w ziemi kapsułę czasu. W środku znalazło się aż 27 artefaktów, które odkryć mają przyszłe pokolenia za okrągły wiek. Należy żywić nadzieję, że w trakcie jej „odkopywania” nie obejdzie się bez archeologa - adepta jednostki o 200-letniej tradycji akademickiej zapoczątkowanej w Poznaniu przez Mistrza Profesora Józefa Kostrzewskiego. 